\title{
The Effect of Strategic Choices and Management Control Systems on Organizational Performance ${ }^{\star}, * *$
}

\author{
Emanuel Junqueira \\ Universidade Federal do Espírito Santo, Centro de Ciências Jurídicas e Econômicas, Departamento de Ciências Contábeis, Vitória, ES, Brazil.
}

Eduardo Vieira Dutra

Universidade Federal do Espírito Santo, Centro de Ciências Jurídicas e Econômicas, Programa de Pós-Graduação em Administração, Vitória, ES, Brazil.

Helio Zanquẹtto Filho

Universidade Federal do Espírito Santo, Centro de Ciências Jurídicas e Econômicas, Programa de Pós-Graduação em Administração, Vitória, ES, Brazil.

Rosimeire Pimentel Gonzaga

Universidade Federal de Minas Gerais, Faculdade de Ciências Econômicas, Departamento de Ciências Contábeis, Belo Horizonte, MG, Brazil.

Received on 04.16.2015 - Desk acceptance on 05.06.2015- $7^{\text {th }}$ version approved on 05.23.2016

\begin{abstract}
The study investigates the effect of generic strategic choices and management control systems (MCS) on the organizational performance of large and medium-sized companies located in Espírito Santo, using Contingency Theory as the theoretical framework. It is a quantitative study, using a survey as the data collection technique. 73 questionnaires were validated, after being completed by those responsible for the controlling or related area of these enterprises over the period between February and April of 2014. The data analysis was performed using the structural equations modeling technique. The main results indicate that: (i) competitive forces shape the strategy adopted by the organizations surveyed, however, contrary to what the literature predicts, those companies that operate in more competitive environments choose a strategy of cost leadership instead of differentiation; (ii) the design and use of the MCS is influenced by the strategy chosen, and the use of contemporary management practices is associated with a differentiation strategy; (iii) strategic choices and the MCS have a positive impact on organizational performance. In addition, those companies that combine differentiation strategy with contemporary management practices perform better than the other companies analyzed.
\end{abstract}

Keywords: contingency theory, management control system, strategic choices.

*The authors thank the support of the Fundação de Apoio à Pesquisa e Inovação do Espírito Santo (FAPES).

**Paper presented at the XXXIX ANPAD Conference (EnANPAD); Belo Horizonte, MG, Brazil, September 2015 


\section{INTRODUCTION}

In the field of organizational studies, contingency theory has provided a coherent paradigm for analyzing the structure of organizations (Donaldson, 2001), and it is one of the main theories used in studies regarding managerial control (Chenhall, 2003; Burkert, Davila, Mehta, \& Oyon, 2014) that analyze the influence of organizational contexts on the design and use of management control systems (MCS) (Hyvönen, 2007).

Claiming that the design and the use of a MCS depend on the context, Hyvönen (2007) used the assumption that there is no universal and ideal structure for all types of organizations (Lawrence \& Lorsch, 1973; Donaldson, 1999, 2001), and that in order for them to be effective and achieve satisfactory performance they need to align their structures with the characteristics of the environment in which they operate (Donaldson, 1999, p. 105).

Contingency theory indicates that organizations should adapt their structure to the contingency. Thus, it is expected that contingency changes cause adjustments in organizational structure, with the aim of avoiding a reduction in performance as a result of failing to adapt (Donaldson, 2001, p. 119).

Despite the emphasis between structural adaptation and performance proposed by contingency theory, the center is not the structure itself, but rather how it is adapted or not to the strategy, which is important for performance (Donaldson, 2001, p. 117), indicating that strategy determines structure (Chandler, 1962).

Therefore, for the authors of contingency theory and the strategic choice approach (Fonseca \& Machado-daSilva, 2002), as well as aligning with the characteristics of the operating environment, the organizational structure, of which the MCS forms part (Moores \& Yuen, 2001), should follow the strategy adopted (Chandler, 1962). Thus, the choice of organizational structure depends on the strategic positioning chosen by the organization (Wood, 2001).

Associating strategic positioning with an organization's operating environment, Porter (1986) claims that the former should be formed based on analysis of what the author considered as competitive market forces, which will compose an organization's operating environment.

Porter's analysis of the competitive market forces model is representative of the Positioning School, which together with the Design School considers the strategic process as being divided into three sequential stages - formulation, implementation, and control; and in which the first stage should occur based on analysis of the environment in which an organization operates (Mintzberg, Ahlstrand, \& Lampel, 2010).

Another assumption of the strategic choice approach refers to the need to adapt an organization's internal abilities to external opportunities, reinforcing the view of Chandler (1962) that organizational structure should follow strategy and suggesting that the choice of a particular strategy should be accompanied by adjustments in the organizational structure (Baines \& Langfield-Smith, 2003; Mintzberg, Ahlstrand, \& Lampel, 2010).

The assumptions of strategic choice theory match those established by contingency theory and assume that there is no MCS model that can be applied to any type of organization in different contexts, or rather, that is unique and universal; they also propose that organizations should adapt their internal structures to the contingencies perceived in the environment in which they operate (Chandler, 1962; Lawrence \& Lorsch, 1973; Donaldson, 1999).

According to the contingency theoretical framework, the elements that are considered as contingent would be those capable of moderating the effect of a particular organizational characteristic with regards to its performance (Donaldson, 2001; Chenhall \& Chapman, 2006).

From this perspective, it is considered that competitive forces analysis has an impact on organizations in their choosing to prioritize differentiation strategy (Porter, 1986); that the strategy shapes the structure (Mintzberg, Ahlstrand, \& Lampel, 2010); and that the MCS forms part of the organizational structure (Khandwalla, 1972; Frezatti, Rocha, Nascimento, \& Junqueira, 2009; Mintzberg, Ahlstrand, \& Lampel, 2010, p. 46-47).

Therefore, it is presumed that the assumptions of the competitive forces model influence the definition of the generic strategies to be adopted and that, since the strategies shape the structure, the management control system will be influenced by the strategy adopted. Also, it is expected that the strategy adopted and the MCS can influence organizational performance (Donaldson, 2001; Chenhall \& Chapman, 2006).

With the aim of empirically verifying the relationships between strategy, structure, and performance, this study seeks to investigate the effect of the generic strategic choices and management control systems (MCS) on the organizational performance of large and medium-sized companies located in Espírito Santo, using contingency theory as the theoretical framework.

To achieve the proposed objective, it was verified whether competitive forces influence the establishment of the generic strategies adopted, as proposed by Porter (1986); whether the strategy adopted influences the MCS design (Chenhall \& Langfield-Smith, 1998); and finally, whether differentiation strategy as a priority and the MCS influence organizational performance (Porter, 1986; Chenhall \& Langfield-Smith, 1998).

In terms of the theoretical-empirical contribution, this 
study is based on filling a gap in the literature identified by Otley (1999) with regards to a lack of studies regarding the possible relationships between the strategies adopted and the management control practices used. Also, for LangfieldSmith (1997), the existing knowledge regarding MCS and strategy is limited, with a lack of research providing new results.

In the view of Aguiar and Frezatti (2007, p. 2) "understanding the contexts in which certain MCS structures are shaped allows it to be predicted when adoption of them can be successful and when changes will be necessary", which would make it possible to avoid wasting resources with structures that are unsuitable to the context of the strategy. A mismatch between MCS features and the context in which an organization operates can cause mismatches between the demand and supply of information, in quantity and quality, which could generate unnecessary costs and a deviation in decision maker focus (Guerra, 2007, p. 112-113).

Moreover, contingent forces influence the structure of organizations and, consequently, the MCS (Covaleski,
Dirsmith, \& Samuel, 1996). In this case, one of the tendencies for identifying and analyzing the appropriate MCS structure is examination of its relationship with organizational performance, considering the effect of the contingent variables, such as environment, technology, and strategy (Chenhall \& Langfield-Smith, 1998; Aguiar \& Frezatti, 2007; Guerra, 2007; Espejo, 2008; Hyvönen, 2008; Junqueira, 2010).

Thus, verifying the relationship between the analysis and formulation of strategic priorities and MCS design in Brazilian companies could widen the empirical field regarding the issue, and also offer practical contributions, since the results found may support elements that could be used to adapt the MCS to the formulation of organizations' strategic priorities.

Moreover, studies that present empirical evidence regarding the relationship between the formulation of strategic priorities, MCS design, and performance, can offer important theoretical contributions for studies on managerial control that use contingency theory as a theoretical base.

\section{THEORETICAL FRAMEWORK AND HYPOTHESES}

Studies that use contingency theory as a theoretical framework seek to identify the influence of contingent variables on organizations. Broadly, these contingencies represent any variable that moderates the effect of an organizational characteristic on its performance.

Thus, the theoretical model proposed for analyzing contingent variables indicates that internal variables reflect the influence of the environment in which an organization operates and its empirical test aims to validate models that propose adaptation between contingent and structural factors in order to maximize organizational performance (Donaldson, 1999, p. 105).

The concept of adaptation (also called fit, adjustment, or association) is widely used by contingency theory and research in the field has aimed to analyze adaptation between environmental contexts and organizational structure, assuming the idea that the greater the adaptation, the better the performance (Guerra, 2007, p. 22).

Donaldson $(1999,2001,2005)$ proposed integrating different contingency approaches in what was called NeoContingency Theory. For McKinley and Mone (2003), the studies by Donaldson represent an evolution in contingency theory and indicate three common elements that exist in different approaches: (i) a connection between contingency and structure; (ii) a process in which changes in contingent variables cause changes in structure; and (iii) adjustment (fit) of structure based on contingencies that affect organizational performance.

These elements are used by Donaldson $(1999$, p. 117) to propose a common theory, underpinning all of the previous approaches, known by him as the theory of structural adaptation in order to regain fit, or SARFIT, in which he proposes an integrated analysis of contingent factors and their effects on structure and on performance, as shown in Figure 1.

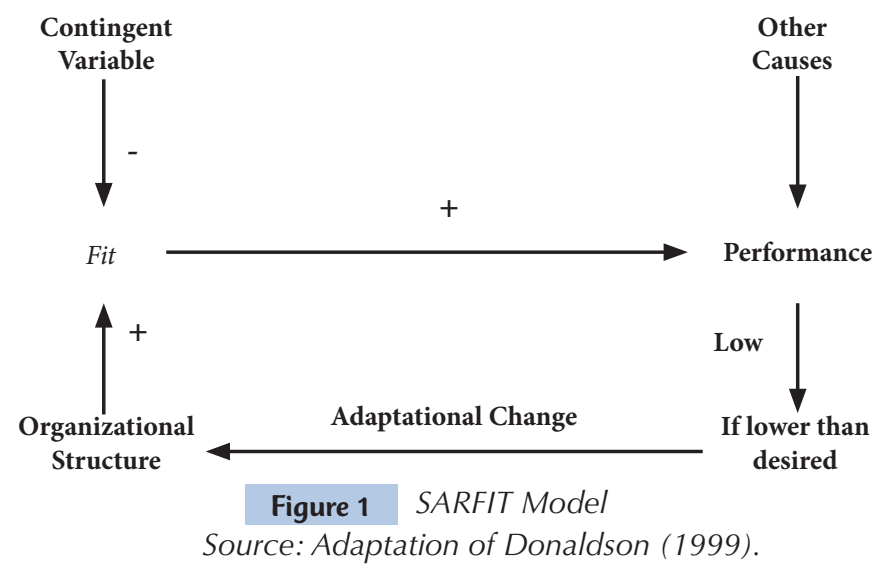


The SARFIT model predicts that an organization is initially fitted, or rather, has a structure adjusted to its level of contingent variables, which is positively reflected in its performance. However, when changes in the contingent variables occur and the existing structure is maintained, the organization becomes misfitted in relation to its level of contingent variables. Consequently, there is a reduction in performance which, becoming unsatisfactory for the owners, leads the company towards an adaptive change, with the aim of finding a new organizational structure adjusted to the new contingent levels and regaining its level of performance.

Studies on managerial accounting based on the assumptions of contingency theory consider that it is not possible to adopt a universal MCS (Otley, 1980); that is, the MCS's design should be structured in function of the environment (Khandwalla, 1977; Hofstede, 1984; Espejo, 2008) and according to the contingencies that are internal to the organization (Khandwalla, 1972; Bruns \& Waterhouse, 1975; Chenhall \& Morris, 1986; Ferreira \& Otley, 2006), and its effectiveness will depend on the ability of the organization to adapt to the changes in these contingent variables (Haldma \& Lääts, 2002, p. 383).

Thus, organizations have experienced periods of adjustment to contingencies (fit), where performance is maximized. However, changes in contingent variables cause a loss in the adjustment between structure and contingencies (misfit), and organizations lose the ability perform optimally, since the ability to perceive and adapt to these changes is what will allow competitiveness to be maintained.

Using contingency theory as a theoretical framework, Chenhall (2003) carried out a review of previous studies and presented a set of proposals regarding the relationship between strategy and MCS. With regards to the generic strategy from Porter (1986), Chenhall (2003) claims that strategies characterized by cost leadership are more associated with formal MCSs and traditional managerial practices, when compared with organizations that use strategies characterized by differentiation leadership, which tend to use less rigid controls and contemporary management practices.

Also interested in studying the relationship between strategy and MCS, Simons (1987) used contingency theory to analyze whether different strategic choices were related to different MCSs. The results indicated that different strategies require different management control practices.

Govindarajan and Fisher (1990) analyzed the cost and differentiation leadership strategies approached by Porter (1986) in a context of resource sharing between business units, and concluded that the benefits of exchanges between units depend on a suitable relationship between the MCS and organizational structure.

Dent (1990) analyzed the relationship between organizational strategies and MCSs. The results found indicated that in order to obtain a competitive advantage an adjustment is necessary between the MCS and organizational strategy. The author also argues that the MCS plays a proactive role in the process of strategic change.

\subsection{Theoretical Constructs of the Analyzed Variables}

\subsubsection{Competitive forces.}

Porter $(1986,1998)$ argues that an organization can obtain a competitive advantage only if it can clearly define its strategy, despite recognizing that there are numerous ways in which organizations position themselves with respect to their environment. Porter (1986) identifies two strategic options, defining them as "generic strategies", which would be: cost leadership and differentiation leadership. Both options can be broad or specific in scope.

For this author, in defining its strategies organizations should carry out an analysis of the "five competitive forces", those being: (i) supplier negotiating power; (ii) buyer negotiating power; (iii) threat from new entrants; (iv) threat from substituting products or services; and (v) rivalry between competitors. In this study, the "Competitive Forces" construct was composed of constructs that represent the five competitive forces suggested by Porter (1986).

\subsubsection{Strategic priorities.}

For operationalization of the "Strategic Priorities" construct, this study opts for the use of the "Generic Strategies" concepts suggested by Porter (1986). The author argues that after analysis of the five competitive forces present in the environment in which organizations operate, the latter should position themselves in order to respond to these forces, opting for a strategy based on low costs or on differentiation, both of which may be broad or narrow in scope.

Some previous studies which have investigated the relationships between contingent factors and the format and/or use of MCSs have used the generic strategies approach from Porter (1986) to define their research constructs and operationalization (Chenhall \& Langfield-Smith, 1998; Baines \& Langfield-Smith, 2003; Chenhall, 2005; Bhimani \& Langfield-Smith, 2007; Guerra, 2007; Carvalho, 2008; Espejo, 2008; Junqueira, 2010; Auzair, 2011; Mantovani, 2012).

According to Porter (1986), organizations that opt for a strategy based on cost leadership should have some advantages such as high market participation, favorable access to raw materials or supplies, work with merchandise which is easily produced or acquired, have a wide range of related products, and have a broad client base. Moreover, the organization should pursue large market niches and be able to generate profit margins, selling large quantities of products and/or services. However, this strategy can bring some disadvantages and dangers, such as the need to offload obsolete assets, investments in technology, maintaining strict cost controls in management, as well as the constant threat 
of imitation of the technologies or methods of cost control on the part of the competition.

Differentiation strategy, for Porter (1986), can represent an alternative to the cost leadership strategy, in which an organization tries to obtain recognition in the market for its unique products or services. Positioning within this strategy can require constant investments in research and development of new products, or in perfecting the services provided. Generally, its products need better quality raw materials, which in some cases are more expensive.

Finally, generic strategies of cost or differentiation leadership can be defined with a narrow scope, called focus. In these cases, an organization opts for a particular type of client, product line, or geographic location, dedicating itself to a specific audience in a small market segment. However, as operations occur in a limited market, the organization seeks to focus on costs or on differentiation, with the same advantages and disadvantages as generic cost or differentiation strategies.

\subsubsection{Management Control System.}

A Management Control System (MCS) can be considered as a set of practices that a particular organization employs for controlling its activities, with different ends, among which is that of providing information that supports managerial decisions. The practices inserted into the MCS can also make it possible for managers to influence the behavior of the other agents in the organization in order to align with the adopted strategies, using monitoring of organizational performance (Berry, Broadbent, \& Otley, 2005).

An MCS is composed of a number of dimensions, with design and use being the two main ones (Ferreira \& Otley, 2006). The design dimension includes the characteristics of the information and techniques used, while the use dimension refers to the way in which the techniques and information are used (Chenhall, 2003).

In this paper the recommendations from Ferreira and Otley (2006, p. 4) are adopted, in relation to the investigation of the design dimension. The chronological criterion employed by them (p. 6-7) is used to classify the management control practices that are components of the design dimension of the MCS. Contemporary practices were considered as being those that arose from the mid 1980s, while the ones previous to this period were considered as being traditional.

Based on the subdivision of MCS into traditional and contemporary practices, it was assumed that traditional management practices are useful for any type of strategic choice (Chenhall \& Langfield-Smith, 1998; Chenhall, 2005; Hyvönen, 2007), that is, traditional management practices are not useful for discriminating the modernity or not of an MCS. Thus, measurement of this construct was chosen by means of contemporary MCS practices. Therefore, the non-use of contemporary techniques by the respondents presupposes the use of traditional MCS practices. The classification proposed by Ferreira and Otley (2006) considers contemporary management control practices to be those presented in Table 1.

Table 1 Contemporary management control practices

\begin{tabular}{ll}
\hline & \multicolumn{1}{c}{ Contemporary Management Control Practices } \\
\hline $\begin{array}{l}\text { Balanced Scorecard or another criterion of balanced performance } \\
\text { evaluating measures }\end{array}$ & Economic Value Added - EVA \\
\hline Budget based on activities & Analysis of product life cycle \\
\hline Costing based on activities & External Benchmarking \\
\hline Intended cost/Target cost & Internal Benchmarking \\
\hline Client profitability analysis & \\
\hline
\end{tabular}

Source: Adapted from Ferreira and Otley (2006).

Coherent with this choice, the other constructs were measured by indicators which, in their extremes on a Likert scale of 1 to 7 points, indicate different configurations, such as cost or differentiation strategy, an MCS with traditional practices or with traditional and contemporary practices. For example, if the indicators related to the strategic priorities are below 3.5 , on average, it would mean that the strategy chosen was close to cost strategy, and the opposite would mean a differentiation strategy.

\subsubsection{Performance.}

According to Oyadomari (2008, p. 19), performance can be captured by different indicators, such as accounting information, market values, combinations between accounting information and market values, and combinations between monetary values and non-monetary values, all of which may be operationalized, also be way of self-assessments.

Supporting Oyadomari (2008), Junqueira (2010, p. 64) claims that studying performance is a complex task, due to 
the difficulty in obtaining access to this information, and recommends the use of compared performance, claiming that this has the advantage of reducing non reply ratios, given that the majority of companies do not publish information related to their performance.

Thus, the perceptions of respondents were used with regards to the performance of the organization in which they worked, compared to the main competitors, in the last three years. This procedure has been adopted in previous studies by Junqueira (2010), Oyadomari (2008), Guerra (2007), Chenhall (2005), Lester, Parnell, and Carraher (2003), and Chenhall and Langfield-Smith (1998).

The performance construct is formed of managers' perception regarding financial measures, such as billing, net income, return on investment, and return on net equity; and non-financial measures, such as new product launches, market participation, and client satisfaction rates. These metrics were similar to those used in studies by Junqueira (2010), Oyadomari (2008), and Guerra (2007), with the exception of the inclusion the "new product launches" variable.

\subsection{Development of Hypotheses}

In accordance with Chenhall (2003, p. 150), strategy is different from the other contingent variables due to it not being a context element, but rather a means by which managers can influence certain internal factors such as technology, structure, culture of control, and MCS.

In relation to the way in which organizations configure themselves in order to adapt to their environment, Guerra (2007) found that companies that operated in an environment with a high level of competition were characterized by the adoption of organic structures and differentiation strategies, while those that were in a stable and protected environment exhibited mechanistic structures and low cost strategies.

Baines and Langfield-Smith (2003) showed that in an environment in which the level of competition is growing, the use of strategies focused on differentiation also grows, suggesting that competitive forces have an influence in determining the generic strategies to be adopted by organizations. Thus, we intend to empirically test the following hypothesis:

$\mathrm{H}_{1}$ : Competitive forces have an influence in determining the strategic priority adopted by companies.

Baines and Langfield-Smith (2003) also argue that the influence of competitive force over the generic strategy adopted influences changes in organizational design, with greater use of structures based on teams, and the adoption of advanced production technologies and management control practices.

Along these lines, some studies have aimed to analyze the influence of contingent factors on the configuration of
MCSs in organizations, among these the strategies adopted (Khandwalla, 1972; Chenhall \& Langfield-Smith, 1998; Baines \& Langfield-Smith, 2003; Guerra, 2007; Espejo, 2008; Reginato, 2010).

According to Khandwalla (1972, p. 281), the intensification of competition leads managers to formalize more sophisticated control mechanisms, indicating, more specifically, a strong relationship between increases in competition between products and more intensive use of control, which has an impact on the format of the MCSs that are responsible for generating such information.

The study by Auzair (2011) indicates that low cost strategies are associated with more bureaucratic MCSs, while differentiation strategies are associated with less bureaucratic MCSs.

Chenhall and Langfield-Smith (1998, p. 245) indicate that certain management control techniques and practices are linked in their degree of importance to the degree with which a cost or differentiation strategy is emphasized, suggesting that the strategy adopted influences the MCS design, as assumed in $\mathrm{H}_{2}$ :

\section{$\mathrm{H}_{2}$ : Strategy shapes companies' MCS design.}

According to Donaldson (2001), models based on contingency theory assume that elements that compose organizational structures, such as the MCS, are related to contingencies, and that the matching or mismatching of elements in this relationship may cause an increase or reduction in performance.

Along these lines, the study carried out by Reginato (2010) found, among other things, an expressive connection between management controls and performance in industrial and services sectors. The study by Soutes (2006) identified that companies that use modern control tools perform better that those that use traditional tools.

Thus, it was expected that in this study the analyzed companies' MCSs would influence their organizational performance, as set out in hypothesis $\mathrm{H}_{3}$ :

\section{$\mathrm{H}_{3}$ : MCS influences companies' organizational performance.}

Just like the MCS, the strategies adopted by a particular company can be considered as contingent factors and therefore are able to influence their performance (Donaldson, 2001; Chenhall \& Chapman, 2006).

In this aspect, Chenhall and Langfield-Smith (1998, p. 256) verified that companies with less emphasis on defining a cost or differentiation strategy perform worse, thus supporting the theory from Porter (1986).

Thus, it would be expected that the strategies adopted by the companies in the sample could influence their organizational performance, as assumed in hypothesis $\mathrm{H}_{4}$ :

$\mathrm{H}_{4}$ : Strategy influences companies' organizational performance. 


\section{METHODOLOGICAL PROCEDURES}

\subsection{Characterization of Study and Selection of Sample and Subject}

This study used a survey as its data collection technique, which was applied to companies listed in the database of the Euvaldo Lodi Institute in the State of Espírito Santo (IEL-ES), and which participated in the 2014 Annual, with a total of 247 companies. The population cross-section chosen was exclusively due to the possibility of accessing the database; however, it should be noted that this State is important for national exports, it is situated in a main economic region of the country, and that the companies that compose the sample represent a significant part of its GDP.

The pre-test was carried out during January 2014, with two researchers from the area and with those responsible for the controlling area of two companies that did not form part of the sample. Small adjustments were made in two questions, with the aim of making them clearer. After the pre-test, the questionnaires were sent, electronically, using the Formsite platform. A first email was sent at the beginning of February 2014, explaining the aim of the study and inviting the companies to take part. The invitation was repeated at the beginning of March and April. The collection of data was concluded at the end of April 2014.

It was requested that a professional from the controlling or equivalent area should reply the questionnaire, with their perception regarding the management practices and strategies adopted by the company. The questionnaire presented five blocks, divided in the following way: (i) competitive forces; (ii) strategic priorities; (iii) management control system; (iv) organizational performance; and (v) company profile and that of the respondent.
The respondent was invited to mark, on a Likert scale of 1 to 7 , their perception regarding aspects related to the environment in which the company operates and to internal questions, which formed the "competitive forces" and "strategic priorities" constructs; to performance compared with the main competitors; and to the level of usefulness to the company of the management control practices. For this last question, if the company did not use a particular management practice, the respondent was invited to mark 0 (zero).

The other, optional questions aimed to collect information regarding company profile and that of the respondents. Out of a total 73 respondents, 53\% identified themselves as president, financial director, financial manager, controller, or accountant of the organization. Another 28\% identified themselves as partner, director, or manager of another area of the company.

Table 2 presents the design of the constructs used in the model, as well as the authors used as references for the composition of the data collection instrument. The conceptual validity of the constructs was developed based on the literature review, with discussions in the study groups with which the researchers are associated. The scales used for the variables that compose the model are seven point Likert ones, as previously mentioned. The semantic development of the questions was carried out based on translation and review of the terms used in the literature, always considering characteristics of the Portuguese language. Due to limited space, the questionnaire is not presented here, but can be made available by the authors to researchers interested in this issue.

Table 2 Aspects investigated in each construct

\begin{tabular}{|c|c|c|c|c|c|}
\hline Question & $\begin{array}{l}2^{\text {nd }} \text { order } \\
\text { Construct }\end{array}$ & $\begin{array}{l}1^{\text {st }} \text { order } \\
\text { Constructs }\end{array}$ & N. of variables & Aspects investigated & References \\
\hline \multirow{5}{*}{1} & \multirow{5}{*}{ Competitive Forces } & Barriers to Entry & 5 & \multirow{5}{*}{$\begin{array}{l}\text { Supplier negotiating power; buyer } \\
\text { negotiating power; threat from } \\
\text { new entrants; threat from substitute } \\
\text { products or services; and rivalry } \\
\text { between competitors. }\end{array}$} & \multirow{5}{*}{ Porter $(1986 ; 1991)$} \\
\hline & & Clients & 5 & & \\
\hline & & Competitiors & 5 & & \\
\hline & & Suppliers & 5 & & \\
\hline & & Substitute Products & 4 & & \\
\hline
\end{tabular}


Table 2 Continued

\begin{tabular}{llll}
\hline & & & \\
\hline 2 & Strategic Priorities & $\begin{array}{l}\text { Investment in advertising; reduction } \\
\text { in costs; research and development; } \\
\text { post-sales and client service; product/ } \\
\text { service differentiation. }\end{array}$ \\
\hline 3 & MCS & 9 & $\begin{array}{l}\text { Contemporary management control } \\
\text { techniques. }\end{array}$ \\
\hline 4 & Performance & Ferreira and Otley (2006) & Financial and non-financial returns. \\
\hline
\end{tabular}

Source: Elaborated by the authors.

With relation to the nature of the measurable first order construct variables related to the "competitive forces" and "strategic priorities" second order constructs, these were developed as constructs of a formative nature. Besides the literature used, the structuring of the questions of this nature facilitated understanding on the part of the respondents. On the other hand, the nature of the measurable variables related to the "management control system" and "performance" constructs were structured in a reflexive way, since the researchers considered this to be the best way for understanding the questions formulated.

85 questionnaires were answered, with 12 being rejected after analysis due to them being incomplete or having being sent using an internet protocol from which a valid questionnaire had already been sent, with 73 valid questionnaires thus being obtained. To calculate the sampling error, a population of 247 (the number of companies that took part in the 2014 IEL-ES data collection) was used, with a sample corresponding to 73 questionnaires.

\subsection{Proposed Model and Data Treatment Criteria}

The data gathered and validated were treated using structural equation modeling based on partial least squares - PLS-SEM, which, according to Hair, Hult, Ringle, and Sarstedt (2014), is a multivariate data technique that allows relationships between constructs and between these indicators to be examined simultaneously.

In relation to the minimum sample size, Hair et al. (2014, p. 16) indicate, among the main PLS-SEM characteristics, that: it generally reaches high levels of statistical power working with small data samples; larger samples increase the precision of the estimations; and a non-parametric statistical method is concerned, in other words it does not require the data to be normally distributed.

The assumptions recommended by Hair et al. (2014, p. 20-21), with regards to the number of formative indicators and the number of structural paths directed towards a single construct, were met. As can be observed in Figure 3, the greatest formative indicator has five measureable variables, and the greatest number of structural paths found is five.

Hair et al. (2014, p. 21) present a table developed by Cohen, in which it is possible to calculate the model's statistical power for different levels of significance. In this study there are a total of 73 respondents and a maximum number of five arrows directed towards the construct. In accordance with the Cohen method, with a 5\% degree of significance, a sample with a minimum size of 70 is necessary in order to obtain an explanatory power of $80 \%$. Thus, it is possible to affirm that the statistical power, with the method used in this study, is greater than $80 \%$, for a $5 \%$ degree of significance. The same authors also mention the possibility of alternatively using another method known as $G^{*}$ Power. However, the authors of this study consider that the methods used fulfill what the literature determines.

The structural equations modeling is characterized by two basic components: (i) the structural model, which relates independent variables with dependent variables; and (ii) the measuring model, which allows the use of indicators to evaluate the contribution of each one in the representation of the variables (Hair, Anderson, Tatham, \& Black, 2005, p. 34-35).

With the aim of facilitating understanding of the hypotheses formulated, the paths model proposed by the study is presented in Figure 2. 


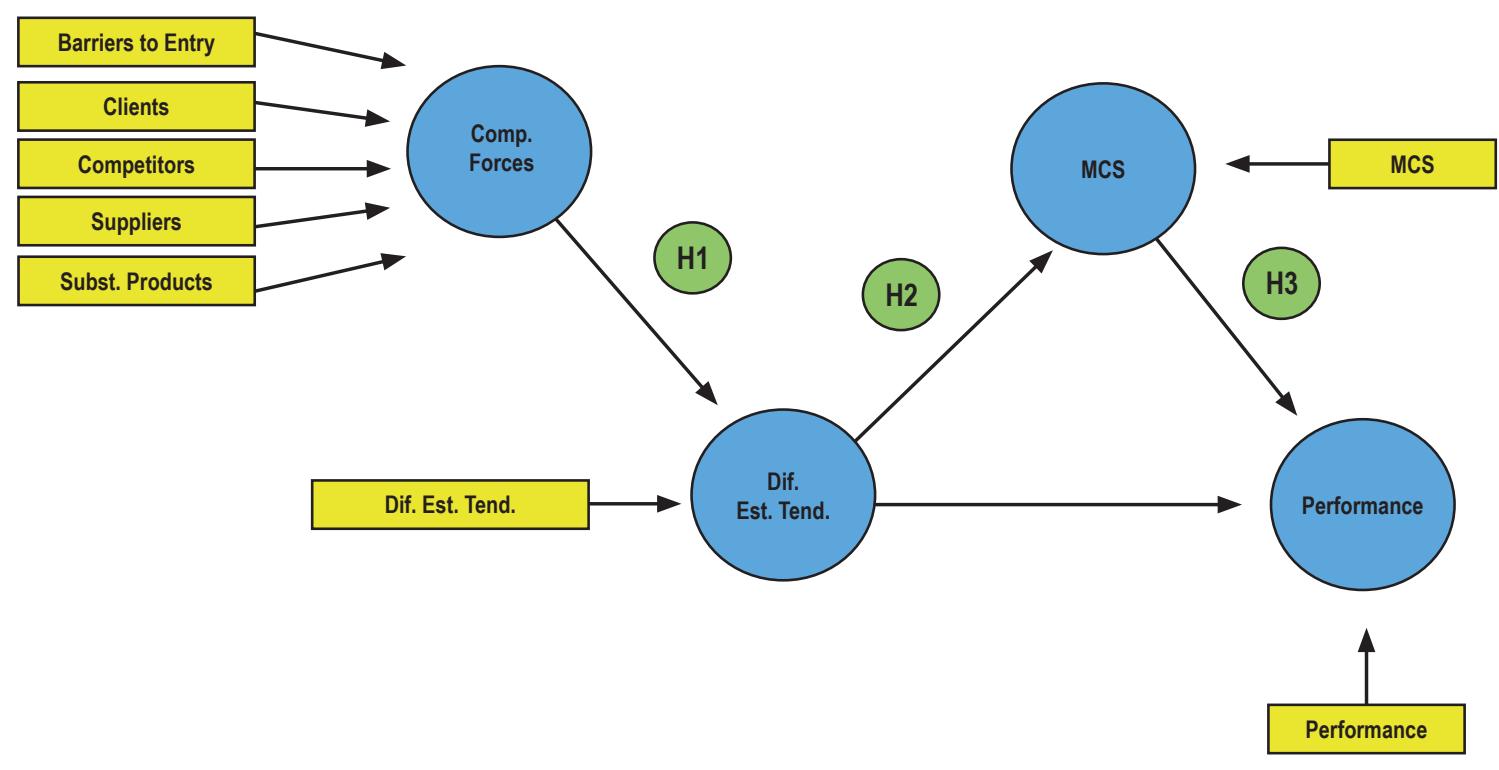

Figure 2 Model of paths proposed in the study Source: Elaborated by the authors.

The Barriers to Entry, Clients, Competitors, Suppliers, and Substitute Products constructs are Lower-order Component (LOC), which represent different aspects of the Competitive Forces construct, which is represented as a Higher-order Component (HOC). That is, the lower order constructs are sub-dimensions of the Competitive Forces construct, and are measured formally, given that each indicator related to each one of the constructs captures an important aspect of them. All the others constructs are first order and measured in a reflexive way. The latent variables that compose the model are presented in Figure 3.

After specification of the structural models and measurement, collection, and examination of the data, and the model estimation via the PLS-SEM algorithm, evaluations of the measurement and structural models were carried out, through analysis of the aspects presented by Hair et al. (2014), such as: internal consistency reliability and convergent and discriminant validities, in the case of the reflexive measurement model; and convergent validity, the existence of collinearity between indicators, and the significance and relevance of the constructs, in the case of the formative measurement model.

For Hair et al. (2014, p. 168), comprehension is important so that "the PLS-SEM matches the model to the data sample in order to obtain a better parameter estimate, by maximizing the explained variance of the endogenous latent variables".

According to these authors (p. 169), in PLS-SEM it is assumed that the model is correctly specified, with it being evaluated for its ability to predict the endogenous latent variables, or rather, the dependent constructs. The authors indicate (p. 230) that the use of a HOC is possible if there is theory to support such a relationship. Together with this, they present a repeated indicators approach, which uses the same indicators used in the LOCs as a way of directly measuring the HOC, which was carried out in the model with the "Competitive Forces" construct.

According to Ringle et al. (2012, apud Hair et al., 2014, p. 233), in formative-formative or reflexive-formative models that apply some hierarchical component, or rather, a HOC represented by LOCs, there are other possible predecessors to the HOC beyond the LOCs related to it. Thus, according to Hair et al. (2014), "these model configurations require special attention when the repeated indicators approach is used in the model for measuring the HOCs, given that almost all of the HOC variance is explained by its LOCs $\left(\mathrm{R}^{2} \approx 1.0\right)$ " (p. 233).

In the event of this type of situation, the authors indicate the use of the two stages approach, represented by a mixture of the repeated indicators approach with the use of latent variable scores. The first stage refers to the use of the repeated indicators approach to obtain the latent variables scores for the LOCs, which in the second stage will serve as manifest variables (indicators) in the model measuring the HOC. Thus, it is possible that new latent variables, if they are inserted into the model, explain part of the HOC variance. 


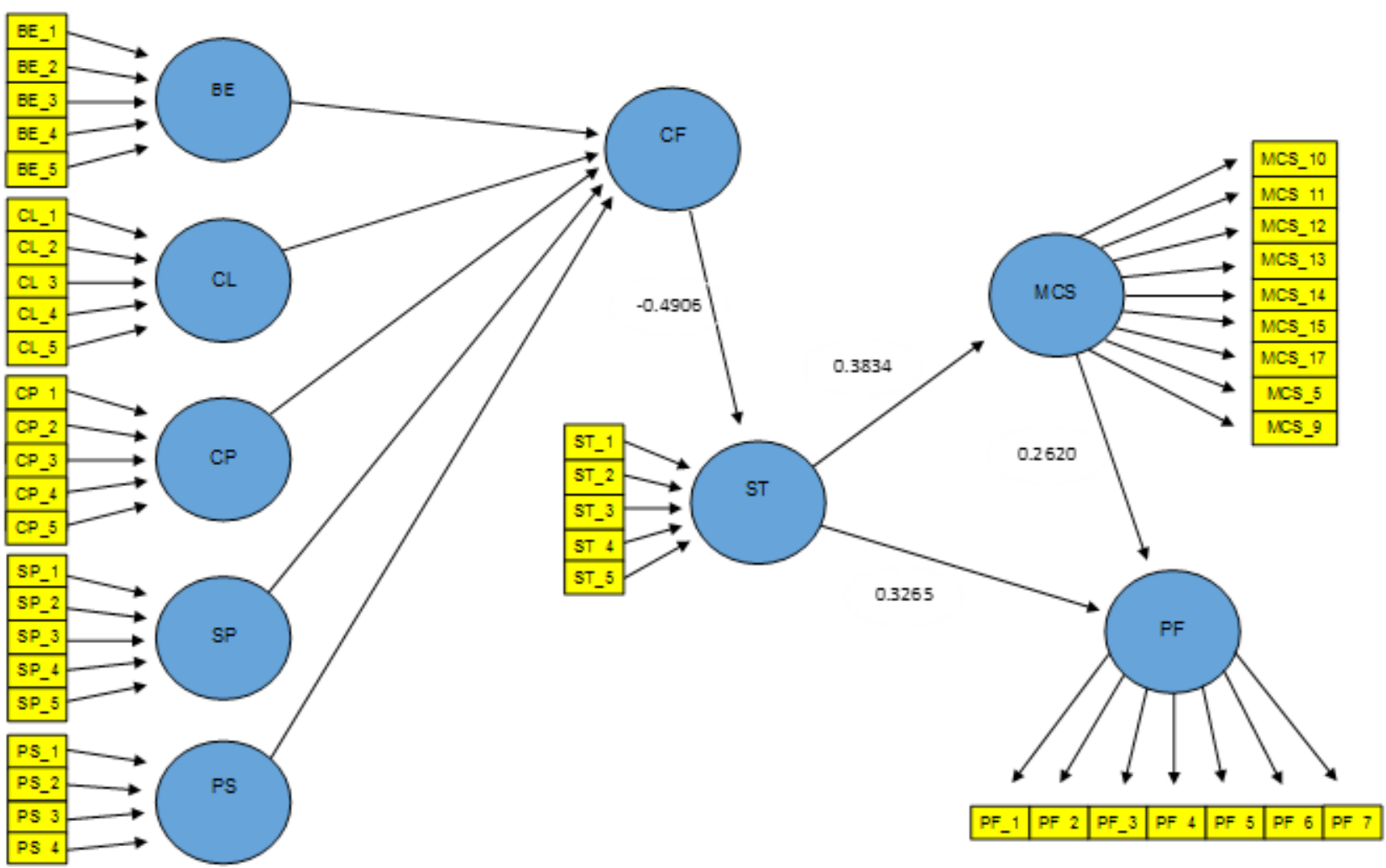

Key: $B E=$ Barriers to Entry; $C L=$ Clients; $C P=$ Competition; $S P=$ Suppliers; $C F=$ Competitive Forces; $P S=$ Products; $S P=$ Strategic Priorities; MCS = Management Control System; PF = Performance.

Figure 3 Final model of research paths Source: Elaborated by the authors.

According to the recommendations from Hair et al. (2014, p. 233; 264-265), the latent variable scores, obtained after running the model presented in Figure 2, were used to estimate the new model (Figure 3), substituting the LOCs and playing the role of manifest HOC variables (indicators), as well as representing the other model constructs. After running SmartPLS 2.0 with these new data, it was possible to carry out the analyses and conclusions, presented below.

As well as the analyses of the path coefficients, the validation of the model was analyzed using the $\mathrm{R}^{2}$, or the determination coefficient, which "represents the amount of variance in the explained endogenous constructs via all the exogenous constructs linked to it" (Hair et al., 2014, p. 174).

According to Hair et al. (2014, p. 175), calculation of the reference values for the determination coefficient is a difficult task, given that it depends on the complexity of the model and the discipline studied. In addition, for these authors, in a study on consumer behavior, values of 0.20 for the $\mathrm{R}^{2}$ are considered as high; in studies that explore drivers of success, such as consumer satisfaction or loyalty, $\mathrm{R}^{2}$ values of at least 0.75 are expected.

\section{RESULTS ANALYSIS}

Initially, some descriptive analyses were carried out regarding the profile of the companies present in the sample. Out of the total, $51 \%$ operate in the services sector, $37 \%$ are from the industrial sector, and $12 \%$ from the commercial sector. With relation to income, $27 \%$ have an annual income of up to $\mathrm{R} \$ 2.4 \mathrm{~m}, 26 \%$ between $\mathrm{R} \$ 2.401 \mathrm{~m}$ and $\mathrm{R} \$ 16 \mathrm{~m}, 9 \%$ between $\mathrm{R} \$ 16.001 \mathrm{~m}$ and $\mathrm{R} \$ 50 \mathrm{~m}, 10 \%$ between $\mathrm{R} \$ 50.001 \mathrm{~m}$ and $\mathrm{R} \$ 90 \mathrm{~m}, 6 \%$ between $\mathrm{R} \$ 90.001 \mathrm{~m}$ and $\mathrm{R} \$ 200 \mathrm{~m}, 5 \%$ between $\mathrm{R} \$ 200.001 \mathrm{~m}$ and $\mathrm{R} \$ 300 \mathrm{~m}$, and finally, $17 \%$ had an income of over $\mathrm{R} \$ 300 \mathrm{~m}$. In relation to the life-cycle of the organizations, $8 \%$ declare themselves to be in the stage of birth, $38 \%$ in growth, $36 \%$ in maturity, $16 \%$ in renewal/ 
rebirth, and $2 \%$ in decline. Thus, it is observed that $74 \%$ of the companies are in the stage of growth or maturity.

\subsection{Evaluation of Measurement Model}

\subsubsection{Reflexive model.}

The two constructs with reflexive indicators in the measurement model, that is, MCS and Performance, present measures of composed reliability and of Cronbach Alpha values, which satisfactorily meet the parameters indicated by Hair et al. (2014, p. 101), 0.8741 and 0.8464 respectively. The composed reliability value, a less conservative criterion for evaluating internal consistency reliability was 0.900 and 0.8744 . For the convergent validity analysis, one indicator presented a load lower than 0.40 , deleg_02 (0.2586), thus being eliminated from the respective construct. The two constructs with reflexive indicators had an AVE above the reference value of $0.50(0.5427 ; 0.5034)$. In the discriminant validity analysis in accordance with the data, using evaluation of the Fornell-Larcker criterion, the square of AVE of each construct was higher than the highest correlation with any other construct; thus no problems were found in this test either.

\subsubsection{Formative model.}

The evaluation of the formative measurement model involves the following stages: (i) evaluation of the convergent validity of the model; (ii) evaluation of the collinearity between the indicators for the same construct; and (iii) evaluation of the significance and relevance of the formative indicators (Hair et al., 2014, p. 120-121).

With relation to the convergent validity, the inclusion of a set of reflexive measures is not particularly desirable, since long surveys can cause fatigue, reduce reply rates, and lead to a greater amount of non-replies (Hair et al., 2014, p. 122). Aiming for prudence in the model, this study did not use reflexive measures in the formatively measured constructs, which would end up generating at least another six indicators, in the case of using global (unique) items. Thus, evaluation of the convergent validity of the formative constructs in the model was not possible.

With relation to collinearity between indicators, the constructs of the model in the study that were measured formatively exhibit tolerance values well above the reference values, with the one that presented the lowest tolerance value being fn_05, with a value of 0.5200 and VIF of 1.9231 . Thus, the formative construct indicators did not present collinearity problems, not showing a high correlation with the other indicators for the same construct.

The last test was that of relevance and significance. In the first order constructs some indicators were observed with significance greater than 0.05: "Barriers to Entry", the "be_2" indicator; "Clients", the "cl_1", "cl_4", and "cl_5" indicators; "Competition", the "cp_2" indicator; and "Suppliers", the "sp_1", "sp_2", and "sp_3" indicators. However, considering construct content validity, since the variables are supported in previous theoretical/empirical papers, it was decided that they would remain in the model, since the removal of the formative variables should take into account the conceptual damages to the model presented. In the "Strategic Priorities" construct, the sp_2 indicator, the degree of significance was above 0.05 . Considering that this construct had its content validity supported in the literature, in the same way it was decided to maintain it in the model, since its removal could generate a loss of content in the first order construct.

\subsection{Path Coefficients Hypothesis Test}

Before beginning the presentation of the results, it is important to present some considerations regarding the possibility of bias in the structural coefficients model, due to the impossibility of using the control variables such as size and/or sector. The classification, carried out by number of employees or by income, indicates that all the companies from the sample are large in size. Moreover, the number of companies in each sector prevents the analysis being carried out in this way.

Thus, even without there being previous theoretical evidence regarding the moderating effect of these variables, since it could not be tested, the possibility of this bias existing in the structural model should be considered; that is, despite the results being conclusive, this observation should be taken into account as a limitation in them. Thus, it is recommended that other researchers can also include them in their models, with the aim of investigating if this moderation exists or not.

In the literature there is the explicit recommendation for including control variables in social science studies, since omitted variables can create bias in the structural coefficients in the model. That is, the inclusion of control variables allows for better results and the possibility of other researchers replicating studies.

On the other hand, Atinc, Simmering, and Kroll (2011) stress that researchers should present theoretical evidence for the need to include control variables, and not include them without a plausible theoretical explanation. In the specific case of this study, no sufficient evidence was found in the literature for control variables to be included in the model. Thus, their inclusion was not characterized as fundamental for analyzing the results, which allowed the researchers to continue with the results analysis. In Table 3, the results from the path coefficients hypothesis test are presented, which will be used in the analysis that follows. 
Table 3 Bootstrapping data for the path coefficients hypothesis test

\begin{tabular}{ccccc}
\hline \multicolumn{5}{c}{ PATH COEFFICIENTS - BOOTSTRAPPING } \\
\hline Hypothesis & Paths & Structural Coefficient & Standard Deviation & T Value \\
\hline $\mathrm{H}_{1}$ & $\mathrm{CF}->\mathrm{SP}$ & -0.4906 & 0.0969 & 5.0643 \\
\hline $\mathrm{H}_{2}$ & $\mathrm{SP}->\mathrm{MCS}$ & 0.3834 & 0.1092 & 0.1062 \\
\hline $\mathrm{H}_{3}$ & $\mathrm{MCS}->\mathrm{PF}$ & 0.262 & 0.1202 & 2.4679 \\
\hline $\mathrm{H}_{4}$ & $\mathrm{SP}->\mathrm{PF}$ & 0.3265 & 2.7159 \\
\hline
\end{tabular}

Source: Elaborated by the authors.

The results analysis indicates that the path coefficient between the Competitive Forces (CF) and Strategic Priorities (SP) constructs is -0.4906 , with a degree of significance of less that $1 \%$. Thus, the $\mathrm{H}_{1}$ hypothesis "Competitive forces have an influence in determining the strategic priority adopted by companies" was not confirmed. Despite being significant, the coefficient is negative. This means affirming that in a more competitive environment the companies studied choose strategies based on costs and not on differentiation. The results are different from those expected by Porter (1986) and Guerra (2007), which indicate that in a more competitive environment differentiation strategy is used.

With relation to the tested hypothesis $\mathrm{H}_{2}$ : "Strategy shapes companies' MCS design", a path coefficient was found between the Differentiation Strategic Priority (SP) and MCS equal to $0.3834(\mathrm{p}<1 \%)$, indicating with more than 99\% reliability that when companies adopt differentiation strategies the MCS contains, predominantly, contemporary management practices. Thus, hypothesis $\mathrm{H}_{2}$ was not rejected, considering that the absolute value of the path coefficient leads to the adoption of contemporary management control practices. This result supports the results found by Chenhall and Langfield-Smith (1998), that is, although a good number of companies in the sample that operate in a highly competitive environment opt for a cost strategy, those that chose a differentiation strategy used contemporary management control practices. Van der Stede (2000) indicates that companies that opt for strategies based on product differentiation use low budgetary control, employing tools with a wider scope, in accordance with the tools that are considered as modern MCS ones. For Chenhall (2003), one of the possible explanations for this result would be the fact that companies that compete by product differentiation need a MCS more focused on planning tools, at the expense of control, while strategies focused on cost leadership require a MCS with more aggregated and integrated information.

For hypothesis $\mathrm{H}_{3}$ : MCS influences companies' organizational performance (PF) - a path coefficient was found between the MCS and Performance constructs of $0.2620(\mathrm{p}<1 \%)$. Thus, it can be inferred that a MCS with management practices considered as contemporary positively affects company performance; therefore, hypothesis $\mathrm{H}_{3}$ was not rejected, and it should also be taken into account that the absolute value of the path coefficient was small in size.

Confirmation of this hypothesis allows for it to be concluded that companies with contemporary practices in their MCSs are able to improve their performance; however, it is necessary to take into account the small size of the coefficient. Thus, the results indicate that despite MCS contributing to company performance, it does not appear to be a decisive element. These results support those found by Ferreira and Otley (2006), and it is understood that the small size found may be associated with the large number of factors that contribute to organizational performance, with it being difficult to find a single factor with a large path coefficient.

The results indicate that the companies in the sample that combine a differentiation strategy with the use of contemporary management practices obtained superior performance to the rest. These results are consistent with other evidence already previously found in the literature from Henri (2006), Mantovani (2012), and Soutes and Guerreiro (2007).

Finally, the coefficient of the path between the Strategic Priorities (SP) and Performance (PF) constructs, regarding testing hypothesis $\mathrm{H}_{4}$. Strategy has an influence on companies' organizational performance, that is, differentiation strategy leads companies to perform better in relation to those that adopt cost strategy, with a coefficient of $0.3265(\mathrm{p}<1 \%)$. Thus, it can be affirmed that the adoption of differentiation strategies has an impact on company performance, leading to the non-rejection of hypothesis $\mathrm{H}_{4}$. These results suggest that companies that adopt a differentiation strategy perform better when compared to those that adopt cost strategy. Finally, it should be considered that the absolute value of the path coefficient is moderate in size. These results are consistent 
with the findings of Porter (1986) and may indicate that all of the sample companies are concerned with managing their costs, and those that opt to simultaneously aim for some type of differentiation achieve greater performance.

\subsection{Determination Coefficients}

Table 4 presents the determination coefficients $\left(\mathrm{R}^{2}\right)$ of the endogenous constructs.

Table 4 Determination coefficients of endogenous constructs

\begin{tabular}{cl}
\hline Construct & $\mathbf{R}^{\mathbf{2}}$ \\
\hline Performance & 0.2409 \\
\hline Strategic Priority & 0.2407 \\
\hline Management Control System (MCS) & 0.147 \\
\hline
\end{tabular}

Source: Elaborated by the authors.

It stands out that in the two stages approach, the "competitive forces" construct was considered as exogenous only, since the lower order constructs were transformed into indicators, with no $\mathrm{R}^{2}$ being generated for these.

The coefficients presented in Table 4 indicate that approximately $24 \%$ of $=$ the companies' variation in performance is related to the manger's strategic priority and also to the MCS used, since these are the only two variables that have an impact on performance in the model presented. This result indicates that, independent of any other factor, the variation in strategic priority and in the MCS used are responsible for $24 \%$ of the variation in the companies' performance.

\section{FINAL REMARKS}

One of the questions that involve organizations' strategic choices is that these would be influenced by the competitive forces model (porter, 1986) and could modify the MCS configuration used (Chenhall \& Langfield-Smith, 1998), given the ability of strategic choices to shape organizational structure.

Thus, this study sought to investigate the effect of generic strategic choices and of MCSs on organizational performance, using contingency theory as a theoretical framework, in a sample of 73 large and medium-sized companies located in the State of Espírito Santos.

The results indicated that companies that operate in more dynamic environments, contrary to expected (Porter, 1986; Guerra, 2007), opt to compete with a cost strategy rather than a differentiation strategy $\left(\mathrm{H}_{1}\right)$. However, the limitations of the study did not allow reasons for this divergence from the theory to be identified, and the causes should be analyzed in future studies. Here it is worth noting the possibility of bias in the coefficients of the structural model, due to the
The analysis of the "competitive forces" variable presented a similar result. Thus, it is observed that the variation in this variable impacts approximately $24 \%$ of the variation in the Strategic Priority (SP) variable, since this is the only variable that has an impact on the model. Thus, independent of the other factors, $24 \%$ of the tendency to choose differentiation as a strategic priority can be explained by the variation in competitive forces.

Finally, it is observed that only $15 \%$ of the variation in the MCS is explained by the organizations' strategic priority. That is, it can be concluded that the tendency for differentiation as a strategic priority does not contribute significantly to the MCS. In other words, the strategic priority does not strongly contribute in the choice of MCS. impossibility of testing the moderating effect with the use of control variables, as discussed in section 4.3.

Another result found refers to the fact that the companies that opt for the differentiation strategy use contemporary management control practices, while those that opt for the costs strategy predominantly use traditional practices $\left(\mathrm{H}_{2}\right)$. This result suggests that companies that opt for differentiation strategies require MCS tools with wider scopes and focused on planning (Van der Stede, 2000; Chenhall, 2003). One of the possible explanations for this result is the fact that the differentiation strategy characteristics require a more flexible structure of control and processes (Chenhall, 2003), implying that companies that operate based on this strategic positioning have an MCS mainly composed of modern tools, given the characteristics of this group of tools. Considering the characteristics of strategies grounded in costs, in this case the MCS takes on another design, being mainly composed of tools focused on control, such as the traditional tools. 
Thus, it is possible to calculate that the strategic choices of the companies in the sample can be considered as one the contingent factors that influence the MCS design dimension.

It should also be noted that, among the results found, the fact that the companies that combine differentiation strategy with the use of contemporary MCS practices obtained higher results than the other companies in the sample $\left(\mathrm{H}_{3}\right)$. This result suggests that contemporary practices may be less relevant for companies that opt for cost strategy, compared with those that opt for differentiation strategy. Moreover, it appears to reinforce the idea that all of the companies, to some extent, are concerned with tools regarding control. However, those which aim for some type of differentiation in the market in which they operate and use tools that are more focused on planning, rather than control, have a differentiated performance.

Also with relation to the companies that opt for differentiation strategies, these perform better than those that opt for cost strategies $\left(\mathrm{H}_{4}\right)$. One possible reason for this result is based on the fact that costs are a common concern in the set of companies studied. Moreover, it should be considered that the companies that combine differentiation strategy with contemporary management strategy perform better than the other companies in the sample, that is, alignment between strategy and MCS is important for improving organizations' performance, as indicated by Chenhall (2003).

In the face of the results found, some implications deserve pointing out, mainly considering three aspects: (i) "incoherence" was identified in testing hypothesis $\mathrm{H}_{1}$, with the opposite result to that presented in the literature. We suggest verifying whether this would be an event specific to this sample, or whether costs are so important in current strategies that they play the main role in any situation; (ii) considering the aspects that are relevant in aligning Strategy and MCS, studies that verify which management systems contribute to this alignment can advance understanding on this issue; and (iii) given that only $24 \%$ of the variation in performance is explained by the variation in Strategy and in MCS, future studies could verify which variables (controllable by managers) are not present in the model and may contribute to organizational performance.

Finally, we hope to have collaborated in stimulating conceptual reflection regarding the issue discussed and also suggest that future studies use samples composed of other companies, in order to construct a broader and more consolidated view on the issue. Moreover, it is important that new studies aim to identify the reasons that determined, in the sample companies, the choice of a different strategy to that expected by the literature.

\section{References}

Aguiar A., \& Frezatti, F. (2007). Sistemas de controle gerencial e contextos do processo de estratégia: contribuições da teoria da contingência. Anais do VII Congresso USP de Controladoria e Contabilidade, São Paulo, SP, Brasil. Recuperado de http://www.congressousp.fipecafi. org/web/artigos72007/34.pdf.

Atinc, G., Simmering, M. J., \& Kroll, M. J. (2011). Control variable use and reporting in macro and micro management research. Organizational Research Methods (ahead of print). DOI: 10.1177/1094428110397773.

Auzair, S. (2011). The effect of business strategy and external environment on management control systems: a study of Malaysian. hotels. International Journal of Business and Social Science, 13(2), 236-244.

Baines, A., \& Langfield-Smith, K. (2003). Antecedents to management accounting change: a structural equation approach. Accounting, Organizations and Society, 28(7), 675-698.

Berry, A., Broadbent, J., \& Otley, D. (2005). Management control: theories, issues and performance (2nd ed.). New York: Palgrave Macmillan.

Bhimani, A., \& Langfield-Smith, K. (2007). Structure, formality and importance of financial and non-financial information in strategy development and implementation. Management Accounting Research, 18(1), 3-31.

Bruns, W., Jr., \& Waterhouse, J. (1975). Budgetary control and organization structure. Journal of Accounting Research, Autumn, p. 177-203.

Burkert, M.; Davila, A.; Mehta, K., \& Oyon, D. (2014) Relating alternative forms of contingency fit to the appropriate methods to test them. Management Accounting Research, 25(1), 6-29.

Carvalho, G. (2008). A influência da internacionalização sobre o controle gerencial de uma empresa brasileira: o caso Sabó Ltda. Master's Degree, Universidade do Estado do Rio de Janeiro, Rio de Janeiro, RJ, Brasil.
Chandler, A. D., Jr. (1962). Strategy and structure: chapters in the history of the American industrial enterprise. Cambridge, MA: MIT Press.

Chenhall, R. (2003). Management control systems design within its organizational context: findings from contingency-based research and directions for the future. Accounting, Organizations and Society, $28,127-168$.

Chenhall, R. H. (2005). Integrative strategic performance measurement systems, strategic alignment of manufacturing, learning and strategic outcomes: an exploratory study. Accounting, Organizations and Society, 30(5), 395-422.

Chenhall, R. H., \& Chapman, C. S. (2006). Theorising and testing fit in contingency research on management control systems. In Z. Hoque (Ed.). Methodological issues in accounting research: theories, methods and issues (pp. 35-52). London: Spiramus Press.

Chenhall, R. H., \& Langfield-Smith, K. (1998). The relationship between strategic priorities, management techniques and management accounting: an empirical investigation using a systems approach. Accounting, Organizations and Society, 23(3), 243-264.

Chenhall, R. H., \& Morris, D. (1986). The impact of structure, environment, and interdependence on the perceived usefulness of management accounting systems. The Accounting Review, 61(1), 16-34.

Covaleski, M., Dirsmith, M., \& Samuel, S. (1996). Managerial Accounting Research: The contributions of organizational and sociological theories. Journal of Management Accounting, 8(1), 1-35.

Dent, J.F. (1990). Strategy, organization and control: some possibilities for accounting research. Accounting, Organizations and Society, 15(12), 3-25.

Donaldson, L. (1999). Teoria da contingência estrutural. In S. Clegg, C. Hardy, \& W. Nord (Orgs.), Handbook de estudos organizacionais (Vol. 1, pp. 105-133). Londres: Sage.

Donaldson, L. (2001). The contingency theory of organizations. London: Sage. 
Donaldson, L. (2005). For positive management theories while retaining science: Reply to Ghoshal. Academy of Management Learning \& Education, 4(1), 109-113.

Espejo, M. (2008). Perfil dos atributos do sistema orçamentário sob a perspectiva contingencial: uma abordagem multivariada. Tese de doutorado, Universidade de São Paulo, São Paulo, SP, Brasil. Recuperado de http://www.teses.usp.br/teses/disponiveis/12/12136/ tde-30062008-141909/pt-br.php.

Ferreira, A., \& Otley, D. (2006). Exploring inter and intra-relationships between the design and use of management control systems [Working Paper]. Monash University, Australia..

Fonseca, V. S., \& Machado-da-Silva, C. L. (2002). Conversação entre abordagens da estratégia em organizações: escolha estratégica, cognição e instituição. Organizações \&. Sociedade, 9(25), 93-109.

Frezatti, F., Rocha, W., Nascimento, A., \& Junqueira, E. (2009). Controle Gerencial: uma abordagem da contabilidade gerencial no contexto econômico, comportamental e sociológico. São Paulo: Atlas.

Govindarajan, V., \& Fisher, J. (1990) Strategy, control systems, and resource sharing: effects on business-unit performance. Academy of Management Journal; 33(2), 259-285.

Guerra, A. (2007). Arranjos entre fatores situacionais e sistema de contabilidade gerencial sob a ótica da teoria da contingência. Dissertação de mestrado, Universidade de São Paulo, São Paulo, SP, Brasil. Recuperado de http://www.teses.usp.br/teses/ disponiveis/12/12136/tde-24052007-085106/pt-br.php.

Hair, J., Jr., Anderson, R., Tatham, R., \& Black, W. (2005). Análise Multivariada de Dados (5a ed.). Porto Alegre: Bookman.

Hair, J. F., Jr., Hult, G. T. M., Ringle, C., \& Sarstedt, M. (2014). A primer on partial least squares structural equation modeling (PLS-SEM). Los Angeles: Sage.

Haldma, T., \& Lääts, K. (2002). Contingencies influencing the management accounting practices of Estonian manufacturing companies. Management Accounting Research, 13(4), 379-400.

Henri, J. F. (2006). Management control systems and strategy: A resource-based perspective. Accounting, Organizations and Society, 31(6), 529-558.

Hofstede, G. (1984). The cultural relativity of the quality of life concept. Academy of Management Review, 9(3), 389-398.

Hyvönen, J. (2007). Strategy, performance measurement techniques and information technology of the firm and their links to organizational performance. Management Accounting Research, 18(3), 343-366.

Hyvönen, J. (2008). Linkịng management accounting and control systems, strategy, information technology, manufacturing technology and organizational performance of the firm in contingency framework. Doctoral Thesis, University of Oulu, Oulu, Finland. Recuperado de http://jultika.oulu.fi/files/isbn9789514287091.pdf

Junqueira, E. (2010). Perfil do sistema de controle gerencial sob a perspectiva da teoria da contingência. Tese de doutorado, Universidade de São Paulo, São Paulo, SP, Brasil. Recuperado de http://www.teses.usp.br/teses/disponiveis/12/12136/tde-10052010143511/pt-br.php

Khandwalla, P. (1972). The effect of different types of competition on the use of management controls. Journal of Accounting Research, 10(2), 275-285.

Khandwalla, P. (1977): The design of organizations. New York: Harcourt, Brace, Jovanovich.

Langfield-Smith, K. (1997). Management control systems and strategy: a critical review. Accounting, Organizations and Society, 22(2), 207-232.

Lawrence, P. R., \& Lorsch, J. W. (1973). As empresas e o ambiente: diferenciação e integração administrativas. Petrópolis: Vozes.
Lester, D. L., Parnell, J. A., \& Carraher, S. (2003). Organizational life cycle: A five-stage empirical scale. The International Journal of Organizational Analysis, 11(4), 339-354.

Mantovani, F. (2012). Desenho e uso de sistemas de controle gerencial focados nos clientes: um estudo em empresas brasileiras sob a perspectiva da teoria da contingência. Tese de doutorado, Universidade de São Paulo, São Paulo, SP, Brasil. Recuperado de http://www.teses.usp.br/teses/disponiveis/12/12136/tde-26062012 153954/pt-br.php.

McKinley, W., \& Mone, M. A. (2003). Micro and macro perspectives in organization theory: A tale of incommensurability. The Oxford handbook of organization theory, 345-372.

Mintzberg, H.; Ahlstrand, B., \& Lampel, J. (2010). Safári de Estratégia: um roteiro pela selva do planejamento estratégico (2a ed.). Porto Alegre: Bookman.

Moores, K., \& Yuen, S. (2001). Management accounting systems and organizational configuration: a life-cycle perspective. Accounting, Organizations and Society, 26(4), 351-389.

Otley, D. T. (1980). The contingency theory of management accounting: achievement and prognosis. Accounting, Organizations and Society, 5(4), 413-428.

Otley, D. (1999). Performance management: a framework for management control systems research. Management Accounting Research, 10(4), 363-382.

Oyadomari, J. C. T. (2008). Uso do sistema de controle gerencial e desempenho: um estudo em empresas brasileiras sob a ótica da VBR (Visão Baseada em Recursos). Tese de doutorado, Universidade de São Paulo, São Paulo, SP, Brasil. Recuperado de http://www.teses.usp. br/teses/disponiveis/12/12136/tde-16012009-112641/pt-br.php

Porter, M. (1986). Estratégia competitiva: técnicas para análise de indústrias e da concorrência (7a ed.). Rio de Janeiro: Campus.

Porter, M. (1991). Estratégia compétitiva: técnicas para análise de indústrias e da concorrência (8a ed.). Rio de Janeiro: Campus.

Porter, M. (1998). Como as forças competitivas moldam a estratégia. In C. A. Montgomery, \& M. E. Porter (Eds.). Estratégia: a busca da vantagem competitiva. Rio de Janeiro: Elsevier.

Reginato, L. (2010). Um estudo setorial sobre as relações entre variáveis ambientais externas, modelos de gestão, controles gerenciais e desempenhos das empresas. Tese de doutorado, Universidade de São Paulo, São Paulo, SP, Brasil. Recuperado de http://www.teses.usp.br/ teses/disponiveis/12/12136/tde-15042010-132200/pt-br.php.

Simons, R. (1987). Accounting control systems and business strategy: an empirical analysis. Accounting, Organizations and Society, 12(4), 357-374.

Soutes, D. (2006). Uma investigação do uso de artefatos de contabilidade gerencial por empresas brasileiras. Dissertação de mestrado, Universidade de São Paulo, São Paulo, SP, Brasil. Recuperado de http://www.teses.usp.br/teses/disponiveis/12/12136/tde-12122006102212/pt-br.php.

Soutes, D. O., \& Guerreiro, R. (2007). Estágios evolutivos da contabilidade gerencial em empresas brasileiras. Anais do XXXI Encontro da Associação Nacional de Pós-Graduação e Pesquisa em Administração, Rio de Janẹiro, RJ, Brasil. Recuperado de http://www. anpad.org.br/admin/pdf/CON-B1934.pdf.

Van der Stede, W. A. (2000). The relationship between two consequences of budgetary controls: budgetary slack creation and managerial short-term orientation. Accounting, Organizations and Society, 25(6), 609-622.

Wood, T., Jr. (2001). Novas configurações organizacionais: pesquisa exploratória empírica sobre organizações locais (Relatório de Pesquisa). São Paulo, SP, Escola de Aḍministração de Empresas de São Paulo, Fundação Getúlio Vargas.

\section{Correspondence Address:}

Emanuel Junqueira

Universidade Federal do Espírito Santo, Centro de Ciências Jurídicas e Econômicas

Av. Fernando Ferrari, 514 - CEP: 29075-910

Goiabeiras - Vitória - ES

Email: ejunqueira@usp.br 